\title{
Shisha use among students in a private university in Kigali city, Rwanda: prevalence and associated factors
}

\author{
Omoboriowo Joad Omotehinwa ${ }^{1 *} \mathbb{D}$, Ogendi Japheths ${ }^{1}$, lyamuremye Jean Damascene ${ }^{2}$ and Michael Habtu'
}

\begin{abstract}
Background: All over the globe shisha smoking is fast growing among different age brackets. Shisha use has been reported to be increasing among youths in African major cities. Its use is documented to result in health effects such as lung cancer, cardiovascular and respiratory conditions, periodontal diseases, keratoacanthoma which are also associated with cigarette smoking. In Kigali, Rwanda's capital, reports indicate that shisha use is increasing among the youths, particularly the university students. The study aimed at determining the prevalence, and establishing factors associated with shisha use among students in a university in Kigali Rwanda, which will be a significant step in stemming shisha fame among youths in Rwanda as there was no previously documented evidence-based study.

Methods: A total of 427 students were selected for this cross-sectional study using stratified sampling method. A questionnaire was used to collect data on shisha use, knowledge about shisha, attitude towards shisha, and factors associated with use of shisha. The association between the independent variables and shisha use was assessed using chi-square $p$ value $<0.05$. Binary logistic regression was used to determine variables that were independently associated with shisha smoking.
\end{abstract}

Results: Prevalence of ever smoking shisha among the university students was $26.1 \%$ and that of those that smoked in the last month (30 days) was 20.8\%. About $40 \%$ (39.9\%) of the participants that had heard about shisha before demonstrated low level of knowledge, and $41.6 \%$ of these reported shisha use in the last 30 days. Logistic regression revealed that the followings were independently associated with shisha smoking: always drink alcohol ( $p=0.003)$; drink alcohol occasionally $(p=0.045)$; having friend(s) who smoke shisha $(p=0.001)$; being aware of shisha's availability in cafes, bars and restaurants in Kigali $(p=0.022)$; positive attitude towards shisha smoking $(p<0.001)$ and participants with age $<20$ years $(p=0.039)$.

Conclusions: There is a relative high prevalence of shisha smoking and a poor knowledge about its impact on health among these university students. Regular medical education and health promotion targeting the youths could improve knowledge and practices about shisha use. Shisha laws and regulations should be enacted, and fines imposed on individuals or group who flout them.

Keywords: Knowledge, Attitude, Shisha smoking, Prevalence, University students, Kigali city, Rwanda

\footnotetext{
* Correspondence: joadieeee@gmail.com

${ }^{1}$ Department of Public Health, Mount Kenya University, School of Health

Sciences, P. O. Box 5826, Kigali Campus, Kigali, Rwanda

Full list of author information is available at the end of the article
}

(c) The Author(s). 2018 Open Access This article is distributed under the terms of the Creative Commons Attribution 4.0 International License (http://creativecommons.org/licenses/by/4.0/), which permits unrestricted use, distribution, and reproduction in any medium, provided you give appropriate credit to the original author(s) and the source, provide a link to the Creative Commons license, and indicate if changes were made. The Creative Commons Public Domain Dedication waiver (http://creativecommons.org/publicdomain/zero/1.0/) applies to the data made available in this article, unless otherwise stated. 


\section{Background}

Tobacco use causes nearly six million deaths globally [1]. It is projected that the attributable mortality due to tobacco smoking will increase from 3 million deaths in 1990 to 8.4 million deaths in 2020 [2]. Tobacco smoking is estimated to cost over US $\$ 500$ billion in economic damage each year globally [3].

Shisha, a form of tobacco smoking, has emerged as a global public health concern and has been described as the 'emerging deadly trend' [4]. Shisha smoking has been significantly linked with similar diseases attributable to cigarette smoking [5] and even more [6]. The aerosol of shisha smoke is reported to have high concentrations of carbon monoxide, nicotine, tar, and heavy metals at concentrations which are as high as or higher than those among cigarette smokers and which are toxic to the human body [7-9]. The practice of shisha smoking is also reported to be capable of spreading infections such as tuberculosis, mononucleosis, viruses and bacteria when the mouth piece is shared [10-12].

It has been documented that shisha smoking is common among the youth mainly high school children, college and university students [13]. Over $60 \%$ of students reported that they had used or were using shisha at the time of a study in a disadvantage secondary school in Johannesburg [14]. Sixty-six percent (66\%) had smoked shisha before and $18 \%$ were current smokers among health science students of the University of Cape Town [15]. High prevalence (36.4\%) of shisha smoking and low knowledge regarding its health effects was reported in youths attending bars in Kampala Uganda [16]. Amongst Sudanese tuberculosis patients and Fayoum University students in Egypt, 7.9 and $8.3 \%$ participants were shisha smokers respectively $[17,18]$. The prevalence of shisha smoking among a United States college population was $64 \%$ for ever smoked shisha and $34 \%$ for smoked shisha within the previous 30 days [19]. Similarly, a study among university students in Beirut revealed that ever shisha smokers were $43 \%$ and current shisha smokers were $28.3 \%$ [20].

In Rwanda, shisha smoking has been described as the "the new craze in Kigali" [21] with the local dailies also describing it as a way of death [22].

Despite these reported concerns about the increasing popularity of shisha smoking amongst the youth in Kigali City of Rwanda, true prevalence of shisha smoking and factors associated with shisha use among the youths, remains unknown. In Rwanda, the government document on control of tobacco is silent on shisha control [23]. Studies on students in Rwanda have addressed Human Immunodeficiency Virus [24, 25] and reproductive health issues [26]. No study on Shisha smoking has focused on this sub population. The National school health policy in Rwanda [27] which outlines notable health problems among students and cited needed approach to address them was also silent on shisha smoking. In December 2017, the Government of Rwanda abolished smoking of shisha in Rwanda and importation of the products for use in shisha smoking [28], in line with World Health Organization Guidelines on Tobacco Use [29]. However, the current prevalence which would act as a baseline data to assess the effect of the ban on shisha smoking in this sub group is lacking.

The purpose of this study was to determine the prevalence and factors associated with shisha use among university students in the city of Kigali. Understanding the prevalence of shisha smoking, knowledge of its health effects and factors associated with shisha use will be of use to practitioners in designing the intervention strategies to this vulnerable group of the population.

\section{Methods}

Design and study population

This was a cross sectional study in which information on the prevalence of shisha use, knowledge of shisha effects, and factors associated with the use of shisha was sought among students from Mount Kenya University, Kigali city Rwanda. Kigali, the capital city of Rwanda, has a population of 1.13 million. Rwanda is a low income country with a gross national income per capita of $\$ 710.0$ [30]. It is one of the countries that form the East African community. The University had a population of 2764 students during the 2016/2017 academic year [31]. The University has four faculties namely: School of Business and social sciences; School of Pure and Applied sciences; School of Health sciences, and School of Education. The University's activities are during the day, in the evenings and on weekends to suit the demand of its prospective students [31].

\section{Sample size and sampling technique}

A total of 427 respondents was calculated using the Cochran formula [32], $n=\mathrm{Z}^{2} \mathrm{pq} / \mathrm{e}^{2}$ whereby: $\mathrm{n}$ is the sample size; $Z$ is the value for the selected alpha level 1.96 for a $95 \%$ confidence level; $\mathrm{p}$ is the estimated prevalence of shisha smoking within the population $(50 \%$, in order to produce the biggest sample size since there was no data on prevalence); e is the acceptable margin of error for the proportion being estimated (assumed to be 5\%); and $q=1-\mathrm{p}$.

Therefore the sample size (n) was $=1.96^{2} \times 0.5 \times 0.5$ / $0.05^{2}=384.16$. Adjustment for non-response of $10 \%$ was calculated by dividing the above sample size by 0.9 thus $384 / 0.9=427$. Stratified sampling method was used [33] , as students were stratified into schools or faculties and then into departments and finally, into program time of study (day, evening and weekend). Using a student's list made available by each department on request, the number of students were chosen based on Probability Proportional to Size after inputting the list into Statistical Package for Social Sciences (SPSS) Version 20. Random selection was done 
using SPSS. Students were approached in lecture rooms shortly before or after a class. The questionnaires were distributed to the selected students, and the absent ones were replaced by running the SPSS again.

\section{Data collection}

A self-administered questionnaire was adapted from a previous shisha study conducted in Kampala Uganda [16]. It was used to obtain information on prevalence of shisha use, knowledge about shisha, attitude towards use of shisha and factors associated with use of shisha. Information sought on prevalence was based on the participants response to the questions "Have you ever smoked shisha" and "Have you smoked shisha in the last month". Ever smoked shisha and smoke shisha in the last month also referred to as current shisha smoking are recommended, standardized definitions of shisha prevalence [34]. Attitude was assessed using a Likert's scale [35]. Responses were categorized as: strongly agree; agree; neither agree nor disagree; disagree and, strongly disagree (see Additional file 1).

The level of knowledge about shisha was assessed based on the ability of the participants to identify diseases associated with Shisha on a 6 point scale adopted from Viscusi Kenkel [36], and response to questions on whether shisha is a form of tobacco and whether it contains nicotine. Correct responses to questions were allocated a value of one giving a possible total of 8 points earmarked to the questions (see Additional file 2). Participants were then categorized as follows: good knowledge, with score of 6 or more; satisfactory knowledge, between 4 and 5 score; low knowledge, between 0 and 3 score.

\section{Data analysis}

Collected data were entered into Epi-data software and imported into SPSS Version 20.0. The descriptive statistics included frequencies, and percentages. Cross tabulations using chi-square test was done to establish relationships between the independent variables and the dependent variable (shisha use). In this study, shisha use in the last month was considered as dependent or outcome variable. Significance level was considered at $p$ value $<0.05$. Multivariable analysis [37] was done with the use of binary logistic regression to determine variables that were independently significant by controlling the confounding variables. During the binary logistic regression, shisha use was defined or coded as ' 1 ' and no shisha use was coded as ' $O$ '.

\section{Ethical consideration}

The study was authorized by the School of Postgraduate Studies and Research Mount Kenya University Rwanda. Before distributing the questionnaire, the researcher informed the students about the objectives of the study, and the confidentiality of their information. All participants had the right not to participate in the study.

\section{Results \\ Socio-demographic and economic characteristics of the respondents}

A total of 427 students were approached for interview of which 418 gave consent to participate (response rate of 97.9\%). Majority (63.1\%) of the respondents were aged 20-24 years and the mean age of participants was 23.8 years. More females (57.7\%) participated in the study. Most (84.7\%) of the respondents were single and $84.4 \%$ of the respondents reside in the urban areas. The highest percentage $(40.6 \%)$ was from the School of Business and Social sciences. Similarly the highest percentage were from the evening program (41.4\%) followed by day program $(37.5 \%)$. The result further revealed that majority (67.5\%) of the respondents were employed and more than half $(56.7 \%)$ belong to category 3 of the social class (Table 1). The categories were based on Rwanda's socio-economic classification referred to as Ubudehe [38].

\section{Prevalence of shisha use}

Of the total of 418 respondents, 109 (26.1\%) indicated that they had ever smoked shisha before while 87 (20.8\%) said they had smoked shisha in the last month. "Smoked shisha in the last month" was used in data analysis and thus is the prevalence of focus in this study.

The main reasons for shisha smoking were curiosity 56 (51.4\%), and peer influence 25 (23.0\%) (Table 2).

\section{Association of socio-demographic and economic characteristics with shisha use}

Table 3 shows socio-demographic and economic characteristics stratified by shisha use. The table shows age $(p=0.002)$, sex $(p=0.007)$, marital status $(p=0.002)$, residence $(p=0.005)$, faculty $(p<0.001)$, mode of study $(p<0.001)$, and family's social class $(p=0.018)$ were significantly associated with shisha smoking.

\section{Knowledge and attitude according to shisha use}

About three-quarters of the respondents, 313 (74.9\%) indicated that they had heard about shisha.

About $40 \%$ of the participants, 125 (39.9\%), who had heard about shisha before demonstrated low level of knowledge while slightly lower proportion, 108 (34.5\%) demonstrated satisfactory level of knowledge. Respondents with low knowledge were significantly more likely to use shisha than those with good knowledge $(p<0.001)$ (Table 4).

Attitude was further classified into positive, neutral and negative attitude. More than half, 246 (58.9\%) of 
Table 1 Socio-demographic and economic characteristics of the respondents

\begin{tabular}{|c|c|c|c|}
\hline Variable & Category & Frequency $(N=418)$ & Percentage (\%) \\
\hline \multirow[t]{4}{*}{ Age in years } & $<20$ & 23 & 5.5 \\
\hline & $20-24$ & 264 & 63.1 \\
\hline & $25-29$ & 78 & 18.7 \\
\hline & $30 \&$ above & 53 & 12.7 \\
\hline \multirow[t]{2}{*}{ Gender } & Male & 177 & 42.3 \\
\hline & Female & 241 & 57.7 \\
\hline \multirow[t]{3}{*}{ Marital status } & Divorced & 13 & 3.1 \\
\hline & Single & 354 & 84.7 \\
\hline & Married & 51 & 12.2 \\
\hline \multirow[t]{2}{*}{ Residence } & Urban & 353 & 84.4 \\
\hline & Rural & 65 & 15.6 \\
\hline \multirow[t]{4}{*}{ Faculty } & School of Business \&social sciences & 170 & 40.6 \\
\hline & School of Pure \& applied sciences & 68 & 16.3 \\
\hline & School of Health sciences & 165 & 39.5 \\
\hline & School of Education & 15 & 3.6 \\
\hline \multirow[t]{3}{*}{ Time of study } & Day & 157 & 37.5 \\
\hline & Evening & 173 & 41.4 \\
\hline & Weekend & 88 & 21.1 \\
\hline \multirow[t]{3}{*}{ Educational level of father } & Tertiary & 247 & 59.1 \\
\hline & Secondary & 139 & 33.3 \\
\hline & Primary & 32 & 7.6 \\
\hline \multirow[t]{3}{*}{ Educational level of mother } & Tertiary & 200 & 47.8 \\
\hline & Secondary & 177 & 42.4 \\
\hline & Primary & 41 & 9.8 \\
\hline \multirow[t]{4}{*}{ Family's social class } & Category 4 & 38 & 9.1 \\
\hline & Category 3 & 237 & 56.7 \\
\hline & Category 2 & 122 & 29.2 \\
\hline & Category 1 & 21 & 5.0 \\
\hline \multirow[t]{2}{*}{ Employment status } & No & 282 & 67.5 \\
\hline & Yes & 136 & 32.5 \\
\hline
\end{tabular}

Table 2 Shisha use among the respondents

\begin{tabular}{|c|c|c|c|}
\hline Variables & Category & Frequency & Percentage (\%) \\
\hline & & $N=418$ & \\
\hline \multirow[t]{2}{*}{ Ever smoked shisha } & No & 309 & 73.9 \\
\hline & Yes & 109 & 26.1 \\
\hline \multirow[t]{3}{*}{ Smoke shisha in the last month } & No & 331 & 79.2 \\
\hline & Yes & 87 & 20.8 \\
\hline & & $N=109$ & \\
\hline \multirow[t]{5}{*}{ Reason for smoking shisha } & Curiosity & 56 & 51.4 \\
\hline & Peer influence & 25 & 23.0 \\
\hline & Stress/Anxiety & 13 & 11.9 \\
\hline & To improve status & 8 & 7.3 \\
\hline & Problem with study/friends & 7 & 6.4 \\
\hline
\end{tabular}


Table 3 Association of socio-demographic \& economic characteristics with shisha use

\begin{tabular}{|c|c|c|c|c|}
\hline \multirow[t]{2}{*}{ Variable } & \multirow[t]{2}{*}{ Category } & \multicolumn{2}{|c|}{ Shisha smoking } & \multirow{2}{*}{$\begin{array}{l}x^{2} \text { test } \\
P \text { value }\end{array}$} \\
\hline & & Yes (\%) & No (\%) & \\
\hline \multirow[t]{4}{*}{ Age in years } & $<20$ & $6(26.1)$ & $17(73.9)$ & \multirow[t]{4}{*}{0.002} \\
\hline & $20-24$ & $58(22.0)$ & 206(78.0) & \\
\hline & $25-29$ & $22(28.2)$ & $56(71.8)$ & \\
\hline & $30 \&$ above & $1(1.9)$ & $52(98.1)$ & \\
\hline \multirow[t]{2}{*}{ Gender } & Male & $48(27.10)$ & 129(72.9) & \multirow[t]{2}{*}{0.007} \\
\hline & Female & $39(16.20)$ & 202(83.8) & \\
\hline \multirow[t]{3}{*}{ Marital status } & Divorced & $6(46.2)$ & $7(53.8)$ & \multirow[t]{3}{*}{0.002} \\
\hline & Single & $78(22.0)$ & $276(78.0)$ & \\
\hline & Married & $3(5.9)$ & 48(94.1) & \\
\hline \multirow[t]{2}{*}{ Residence } & Urban & $82(23.2)$ & $271(76.8)$ & \multirow[t]{2}{*}{0.005} \\
\hline & Rural & $5(7.7)$ & $60(92.3)$ & \\
\hline \multirow[t]{4}{*}{ Faculty } & School of Business \&social sciences & $51(30.0)$ & 119(70.0) & \multirow[t]{4}{*}{0.000} \\
\hline & School of Pure \& applied sciences & $20(29.4)$ & 48(70.6) & \\
\hline & School of Health sciences & $14(8.5)$ & 151(91.5) & \\
\hline & School of Education & $2(13.3)$ & 13(86.7) & \\
\hline \multirow[t]{3}{*}{ Time of study } & Day & 23(14.6) & 134(85.4) & \multirow[t]{3}{*}{0.000} \\
\hline & Evening & 55(31.8) & $118(68.2)$ & \\
\hline & Weekend & $9(10.2)$ & 79(89.8) & \\
\hline \multirow[t]{3}{*}{ Educational level of father } & Tertiary & 54(21.9) & 193(78.1) & \multirow[t]{3}{*}{0.696} \\
\hline & Secondary & $28(20.1)$ & $111(79.9)$ & \\
\hline & Primary & $5(15.6)$ & $27(84.4)$ & \\
\hline \multirow[t]{3}{*}{ Educational level of mother } & Tertiary & $45(22.5)$ & $155(77.5)$ & \multirow[t]{3}{*}{0.081} \\
\hline & Secondary & $39(22.0)$ & 138(78.0) & \\
\hline & Primary & $3(7.3)$ & $38(92.7)$ & \\
\hline \multirow[t]{4}{*}{ Family's social class } & Category 4 & $15(39.5)$ & $23(60.5)$ & \multirow[t]{4}{*}{0.018} \\
\hline & Category 3 & $42(17.7)$ & 195(82.3) & \\
\hline & Category 2 & $27(22.1)$ & 95(77.9) & \\
\hline & Category 1 & $3(14.3)$ & 18(85.7) & \\
\hline \multirow[t]{2}{*}{ Employment status } & No & 55(19.5) & $227(80.5)$ & \multirow[t]{2}{*}{0.342} \\
\hline & Yes & $32(23.5)$ & 104(76.5) & \\
\hline
\end{tabular}

$p$ value for Faculty has been italicized

$p$ value for Time of study also italicized

the respondents had negative attitude towards shisha smoking. Respondents with positive attitude towards shisha were more significantly to use shisha than those with negative and neutral attitude $(\mathrm{p}<0.001)$ (Table 4).

\section{Environmental, lifestyle, and behavioral factors stratified by shisha use}

Most (70.3\%) of the respondents were not drinking alcohol. Likewise, most (87.8\%) of the respondents enjoy being in school. More than half (57.9\%) of the respondents were participating in sport regularly. Majority (61.2\%) were living with their parents and most of their parents $(85.2 \%)$ were not smoking tobacco.
Similarly, most siblings (58.6\%) were not smoking any form of tobacco. Considerable percentage (40\%) reported their friend(s) smoke shisha whereas $49.3 \%$ reported their friend(s) smoke conventional cigarette. It also highlights that most respondents (58.1\%) were aware of shisha's availability in cafes, bars and restaurants in Kigali (Table 5).

The bivariate analysis indicated that the following were significantly associated with shisha use: alcohol drinking $(p<0.001)$, respondents whose parents smoke tobacco $(p=0.006)$, respondents whose friends smoke shisha $(p<0.001)$, respondents whose friends smoke cigarette $(p<0.001)$ and respondents who were 
Table 4 Knowledge, attitude and shisha use

\begin{tabular}{|c|c|c|c|c|c|}
\hline \multirow[t]{2}{*}{ Variable } & \multirow[t]{2}{*}{ Category } & \multicolumn{2}{|c|}{$\begin{array}{l}\text { Shisha smoking } \\
N=418\end{array}$} & \multirow{2}{*}{$\begin{array}{l}\text { Total } \\
N=418(\%)\end{array}$} & \multirow{2}{*}{$\begin{array}{l}x^{2} \text { test } \\
p \text { value }\end{array}$} \\
\hline & & Yes (\%) & No (\%) & & \\
\hline \multirow[t]{3}{*}{ Ever heard about shisha } & No & $0(0.0)$ & $105(100)$ & $105(25.1)$ & \\
\hline & Yes & $87(27.8)$ & $226(72.2)$ & $313(74.9)$ & \\
\hline & & $N=313$ & & $N=313(\%)$ & \\
\hline \multirow[t]{4}{*}{ Level of knowledge ( $N=313$ ) } & Good & 13(12.0) & 95(88.0) & 108(34.5) & 0.000 \\
\hline & Satisfactory & $22(27.5)$ & $58(72.5)$ & $80(25.6)$ & \\
\hline & Low & $52(41.6)$ & $73(58.4)$ & 125(39.9) & \\
\hline & & $N=418$ & & & \\
\hline \multirow[t]{3}{*}{ Attitude } & Positive attitude & $50(47.6)$ & $55(52.4)$ & $105(25.1)$ & 0.000 \\
\hline & Neutral attitude & 7(10.4) & $60(89.6)$ & $67(16.0)$ & \\
\hline & Negative attitude & $30(12.2)$ & 216(87.8) & $246(58.9)$ & \\
\hline
\end{tabular}

$p$ value for Level of knowledge italicized

$p$ value for Attitude italicized

Table 5 Environmental, lifestyle, and behavioral factors stratified by shisha use

\begin{tabular}{|c|c|c|c|c|c|}
\hline \multirow[t]{2}{*}{ Variable } & \multirow[t]{2}{*}{ Category } & \multicolumn{2}{|c|}{ Shisha smoking } & \multirow{2}{*}{$\begin{array}{l}\text { Total } \\
N=418(\%)\end{array}$} & \multirow{2}{*}{$\begin{array}{l}X^{2} \text { test } \\
P \text { value }\end{array}$} \\
\hline & & Yes (\%) & No (\%) & & \\
\hline \multirow[t]{3}{*}{ Enjoy being in school } & Yes & $76(20.7)$ & $291(79.3)$ & $367(87.8)$ & 0.711 \\
\hline & Not sure & $7(25.9)$ & $20(74.1)$ & $27(6.5)$ & \\
\hline & No & $4(16.7)$ & 20(83.3) & $24(5.7)$ & \\
\hline \multirow[t]{2}{*}{ Regularly participate in sports } & Yes & $52(21.5)$ & $190(78.5)$ & $242(57.9)$ & 0.691 \\
\hline & No & $35(19.9)$ & $141(80.1)$ & $176(42.1)$ & \\
\hline \multirow[t]{3}{*}{ Drink Alcohol } & Yes & $35(44.3)$ & $44(55.7)$ & 79(18.9) & 0.000 \\
\hline & Occasionally & 13(28.9) & $32(71.1)$ & $45(10.8)$ & \\
\hline & No & $39(13.3)$ & 255(86.7) & $294(70.3)$ & \\
\hline \multirow[t]{2}{*}{ Lives with parent(s) } & Yes & $61(23.8)$ & 195(76.2) & $256(61.2)$ & 0.056 \\
\hline & No & $26(16.0)$ & $136(84.0)$ & 162(38.8) & \\
\hline \multirow[t]{3}{*}{ Sibling(s) smoke tobacco } & Yes & $21(29.6)$ & $50(70.4)$ & $71(17.0)$ & 0.125 \\
\hline & No & 48(19.6) & 197(80.4) & $245(58.6)$ & \\
\hline & Don't know & 18(17.6) & $84(82.4)$ & $102(24.4)$ & \\
\hline \multirow[t]{3}{*}{ Parent(s) smoke tobacco } & Yes & $17(39.5)$ & $26(60.5)$ & $43(10.3)$ & 0.006 \\
\hline & No & $66(18.5)$ & $290(81.5)$ & $356(85.2)$ & \\
\hline & Don't know & $4(21.1)$ & 15(78.9) & $19(4.5)$ & \\
\hline \multirow[t]{2}{*}{ Friend(s) smoke shisha } & Yes & $72(43.1)$ & 95(56.9) & 167(40.0) & 0.000 \\
\hline & No & $15(6.0)$ & 236(94.0) & $251(60.0)$ & \\
\hline \multirow[t]{2}{*}{ Friend(s) smoke cigarette } & Yes & 65(31.6) & $141(68.4)$ & 206(49.3) & 0.000 \\
\hline & No & $22(10.4)$ & 190(89.6) & $212(50.7)$ & \\
\hline \multirow[t]{2}{*}{ Aware of shisha's availability in cafes, bars in Kigali } & Yes & $81(33.3)$ & $162(66.7)$ & 243(58.1) & 0.000 \\
\hline & No & $6(3.4)$ & 169(96.6) & 175(41.9) & \\
\hline
\end{tabular}

$p$ value for Drink alcohol italicized

$p$ value for Friend smoke shisha italicized

$p$ value for Friend smoke cigarette italicized

$p$ value for Aware of shisha's availability in cafes italicized 
Table 6 Factors independently associated with shisha use

\begin{tabular}{|c|c|c|c|c|c|c|c|}
\hline \multirow[t]{2}{*}{ Variable } & \multirow[t]{2}{*}{ Category } & \multicolumn{2}{|c|}{ Shisha smoking } & \multirow[t]{2}{*}{ AOR } & \multicolumn{2}{|l|}{$95 \% \mathrm{Cl}$} & \multirow[t]{2}{*}{$P$ value } \\
\hline & & Yes (\%) & No (\%) & & Lower & Upper & \\
\hline \multirow[t]{4}{*}{ Age in years } & $<20$ & $6(26.1)$ & $17(73.9)$ & 15.24 & 1.152 & 201.761 & 0.039 \\
\hline & $20-24$ & $58(22.0)$ & 206(78.0) & 5.48 & 0.591 & 50.756 & 0.134 \\
\hline & $25-29$ & $22(28.2)$ & $56(71.8)$ & 8.18 & 0.841 & 79.544 & 0.070 \\
\hline & 30 \& above & $1(1.9)$ & $52(98.1)$ & Ref & & & \\
\hline \multirow[t]{3}{*}{ Drink Alcohol } & Yes & $35(44.3)$ & $44(55.7)$ & 3.03 & 1.475 & 6.216 & 0.003 \\
\hline & Occasionally & $13(28.9)$ & $32(71.1)$ & 2.60 & 1.021 & 6.619 & 0.045 \\
\hline & No & $39(13.3)$ & 255(86.7) & Ref & & & \\
\hline \multirow[t]{2}{*}{ Friend(s) smoke Shisha } & Yes & $72(43.1)$ & $95(56.9)$ & 3.46 & 1.646 & 7.281 & 0.001 \\
\hline & No & $15(6.0)$ & 236(94.0) & Ref & & & \\
\hline \multirow[t]{2}{*}{ Aware of shisha's availability in cafes, bars\& rest. in Kigali } & Yes & $81(33.3)$ & 162(66.7) & 3.27 & 1.186 & 9.031 & 0.022 \\
\hline & No & $6(3.4)$ & 169(96.6) & Ref & & & \\
\hline \multirow[t]{3}{*}{ Attitude } & Positive & $50(47.6)$ & $55(52.4)$ & 3.32 & 1.697 & 6.478 & 0.000 \\
\hline & Neutral & $7(10.4)$ & $60(89.6)$ & 0.85 & 0.291 & 2.479 & 0.766 \\
\hline & Negative & $30(12.2)$ & 216(87.8) & Ref & & & \\
\hline
\end{tabular}

AOR Adjusted Odds Ratio, Ref reference

$p$ value for Attitude italicized

aware about shisha availability in cafes, restaurants and bars $(p<0.001)$ (Table 5).

\section{Factors independently associated with shisha use}

Multiple logistic regression was applied to establish factors independently associated with shisha use (Table 6). All the factors associated with shisha use during bivariate analysis were considered together in the multivariable analysis. After running the multivariable analysis by specifying backward conditional method, the following five variables were independently associated with shisha smoking: age, always drink alcohol, occasionally drinks alcohol, friend(s) smoke shisha, aware of shisha's availability in cafes, bars and restaurants in Kigali as well as attitude towards shisha.

\section{Discussion}

Our findings indicate that the prevalence of the students who reported to have 'smoked shisha in the last month' in a private university in Kigali city, Rwanda, was $20.8 \%$. This is similar to prevalence rates for 'smoked shisha in the last month' that have been previously reported among youth in Estonia (21\%), Czech Republic (22.1\%), and in Latvia (22.7\%) [39]. It also agrees with the findings of studies in Pakistan, where the prevalence of shisha use among students in a medical institution was reported as $21.5 \%$ [40], and in Lebanon, where the prevalence of current shisha smoking was $22.1 \%$ [41].

The prevalence of shisha smoking indicated in this study, however, is lower than those reported among youths in Kampala, where the prevalence of current shisha smoking was reported to be $36.4 \%$ [16], the reported prevalence of current shisha smokers among youth in Lebanon (36.9\%) and in West Bank (32.7\%) [39]. In Johannesburg, the prevalence of youth who reported that they had used shisha before or were using shisha at the time of the study was 60\% [14], about three times the reported prevalence amongst the university students in Kigali City.

From the public health perspective, the findings of this study that the prevalence of shisha use is higher than the prevalence values that have been reported in studies among youth in other areas like in Southern California (10.7\%) [42], United Arab Emirates (5.6\%) [43] and Saudi Arabia (8.6\%) [44], would suggest that an opportunity exists for the public health practitioners charged with the mandate of reducing the burden of shisha smoking among the youth to put in place intervention strategies that could lower the prevalence of shisha smoking amongst the youths.

It could also be important to have insights derive from studies on these communities why much lower prevalence values exist among the youths in those communities. It would also provide good practical lessons of public health significance to be learnt from those communities that the public health intervention strategists in the city of Kigali and other similar populations could possibly adapt and adopt.

The banning of shisha use in Rwanda has come after earlier bans in other East African countries like Uganda 2015 [45], and in Tanzania in 2016 [46]. Unfortunately, there has been widespread attention focused on the dangers of cigarette smoking and increasing efforts to discourage cigarette smoking, but comparatively less attention has been put to dangers of shisha use [47]. 
Our findings reveal that $60 \%$ of the respondents had satisfactory and good knowledge about shisha and its negative effect. Although comparatively lower proportion, about $40 \%$, of the participants who had heard about shisha before demonstrated low level of knowledge about shisha, participants with low knowledge were shown to be more likely to use shisha than those with satisfactory knowledge and good knowledge.

This is supported by a study among adolescents in Saudi Arabia where participants with the knowledge score of $<4$ were $56.3 \%$ among ever smokers and $38.2 \%$ among never smokers reflecting overall low knowledge about the health hazard of shisha smoking $(p=0.004)$ [48]. Among youths in Kampala, $67.7 \%$ of the participants had poor knowledge about shisha and its health effects [16].

The finding of this study is of importance to health promotion experts. Improving knowledge level on the dangers of shisha amongst the youth should be an important focus to those targeting the health of the youths in health promotion.

Consistent with previous reports [49-51], alcohol drinking (always drink alcohol and drink alcohol occasionally) was independently associated with shisha smoking. Also, having friends who smoke shisha was associated with shisha use. This supports the previous findings that having close friend(s) who smoked was identified as an important risk factor towards adolescents tobacco use among Iraqi students [52], and that more than half (59.2\% females and $61.3 \%$ males participants) that were shisha smokers in a study in Kuwait said all or most of their friends smoked shisha [47].

In this study, it was found out that age below 20 years was independently associated with shisha use. This is in congruent with other studies where younger age was significantly associated with hookah smoking among U.S. students [53], among Southeast Michigan adults [54], and on a U.S. college campus [55]. Young people's risk taking, experimentation, and vulnerability to peer pressure have been argued to be necessary parts of the individualization process, required for full identity achievement [56]. Public health intervention strategists should target these young age brackets in health education and promotion.

Participants who demonstrated positive attitude towards shisha were also associated with shisha smoking. This is consistent with studies in Kuwait where shisha smokers had more positive attitudes towards shisha smoking and were less likely to believe in its harmful effects [47], and among university students in Iraq where positive attitude towards smoking was reported as a significant predictor for current shisha smoking $(p<0.001)$ [51]. Public health intervention in the form of health promotion is needed to build the right attitude towards shisha use. It should be introduced early into the schools' curriculum, and in collaboration with the media outlets, should emphasize on the detrimental effects and impending danger associated with shisha use.

The findings in this study indicated that curiosity, peer influence, stress/anxiety, to improve status, and problem with study/friends were reason for shisha smoking. Among university students in Pakistan, curiosity was found to be the most common reason (61.4\%), followed by pleasure-seeking $(46.9 \%)$, peer pressure $(22.8 \%)$, boredom (17.8\%) and stress (10.8\%) [57]. In a University in Malaysia, shisha smoking was associated with problems among friends [58]. Peer pressure is a potent factor influencing smoking behavior. Understanding the dynamics of friendship patterns (both male and female) should be an important consideration in an effort to unravel the problems of youths' health in this regard. This had been the focus of western social scientists for some time; however friendship patterns have not been studied among African youth. There is a need for studies on this topic, if effective programs to discourage smoking among young people are to be developed.

\section{Limitation}

The findings of this study were based in Kigali city and the findings may not represent universities situated in non-urban districts. Another limitation was that the findings presented in this study were based on self-report and there was no way of ascertaining the reliability of the participants' responses.

\section{Conclusion}

Shisha is a popular form of tobacco smoking among these private university students in Kigali. This warrants increase shisha surveillance among this group and with the newly implemented ban on shisha use, advertisement and importation [15], measures should be put in place to effect strict implementation as well as impose fines on whoever flouts the regulations.

\section{Additional files} Additional file 1: Attitude of respondents towards shisha smoking.
(DOCX $20 \mathrm{~kb})$

Additional file 2: Knowledge of shisha and its health effects. (DOCX $17 \mathrm{~kb}$ )

\section{Abbreviations}

AIDS: Acquired Immunodeficiency Syndrome; AOR: Adjusted Odds Ratio; Cl: Confidence Interval; HIV: Human Immunodeficiency Virus; MKU: Mount Kenya University; REF: Reference; SPSS: Statistical Package for the Social Sciences; U.S: United States; UK: United Kingdom; USA: United States of America; WHO: World Health Organization

\section{Acknowledgements}

We would like to thank the participants in this study for accepting to be interviewed and all staff of Mount Kenya University Kigali Rwanda for support in making this study possible. 


\section{Availability of data and materials}

The dataset supporting the findings of this article is available upon request.

\section{Authors' contributions}

OJO is the guarantor of the article. OJO, OJ, HM and IJD contributed to the conception and design of the study, the analysis and interpretation of data and results, and the drafting and revisions of the paper. OJ and HM participated in the interpretation of data and results. All authors have critically revised the text for important intellectual content and have read and approved the final manuscript and are accountable for all aspects of the work.

\section{Ethics approval and consent to participate}

The ethical aspect of this study was approved by School of Postgraduate Studies and Research Mount Kenya University Rwanda (no reference number). Before collecting data, the researcher explained to respondents the purpose of the research so that they have complete understanding of what is expected from them and signed informed consent was obtained. The data were only used for research purpose by the researcher.

\section{Competing interests}

The authors declare that they have no competing interests.

\section{Publisher's Note}

Springer Nature remains neutral with regard to jurisdictional claims in published maps and institutional affiliations.

\section{Author details}

'Department of Public Health, Mount Kenya University, School of Health Sciences, P. O. Box 5826, Kigali Campus, Kigali, Rwanda. ${ }^{2}$ Rwanda Biomedical Center, Ministry of Health Kigali, Kigali, Rwanda.

Received: 17 January 2018 Accepted: 23 May 2018

Published online: 08 June 2018

\section{References}

1. World Health Organization T. WHO report on the global tobacco epidemic, 2011: warning about the dangers of tobacco. Most. 2011;152:1-152. Available from: http://www.who.int/about/licensing/\%5Cnhttp://whqlibdoc. who.int/publications/2011/9789240687813_eng.pdf

2. Lopez AD, Murray CCJ. The global burden of disease, $1990-2020$. Nat Med. 1998:4(11):1241-3

3. World Health Organization. WHO report on the global tobacco epidemic: Enforcing bans on tobacco advertising, promotion and sponsorship. Geneva; 2013. Available from: http://www.afro.who.int/publications/whoreport-global-tobacco-epidemic-2013.

4. American Lung Association. An Emerging Deadly Trend: Waterpipe Tobacco Use. Tob Policy Trend Alert. 2007:1-9. Available from: https://www.sribd. com/document/36779247/Tobacco-Policy-Trend-Alert.

5. Raad D, Gaddam S, Schunemann HJ, Irani J, Abou Jaoude P, Honeine R, et al. Effects of water-pipe smoking on lung function: a systematic review and meta-analysis. Chest. 2011;139(4):764-74.

6. El-Hakim IE, Uthman MAE. Squamous cell carcinoma and keratoacanthoma of the lower lip associated with "Goza" and "Shisha" smoking. Int J Dermatol. 1999;38(2):108-10.

7. Cobb CO, Shihadeh A, Weaver MF, Eissenberg T. Waterpipe tobacco smoking and cigarette smoking: a direct comparison of toxicant exposure and subjective effects. Nicotine Tob Res. 2011;13(2):78-87.

8. Eissenberg T, Shihadeh A. Waterpipe tobacco and cigarette smoking. Am J Prev Med. 2009;37(6):518-23. Available from: https://www.ajpmonline.org/ article/S0749-3797(09)00583-2/fulltext.

9. Knishkowy B. Water-pipe (Narghile) smoking: an emerging health risk behavior. Pediatrics. 2005;116(1):e113-9. Available from: http://pediatrics. aappublications.org/content/116/1/e113.

10. Hakim F, Hellou E, Goldbart A, Katz R, Bentur Y, Bentur L. The acute effects of water-pipe smoking on the cardiorespiratory system. Chest 2011;139(4): 775-81. Available from: http://www.ncbi.n/m.nih.gov/pubmed/21030492.

11. Habib M, Mohamed MK, Abdel-Aziz F, Magder LS, Abdel-Hamid M, Gamil F, et al. Hepatitis $C$ virus infection in a community in the Nile Delta: risk factors for seropositivity. Hepatology (Baltimore, Md.). 2001;33(1):248-53. Available from: https://doi.org/10.1053/jhep.2001.20797.pdf (accessed 06 Apr 2018)
12. Steentoft J, Wittendorf J, Andersen JR. Tuberculosis and water pipes as source of infection. Ugeskr Laeger. 2006;168(9):904-7. Retrieved from http:// www.ncbi.nlm.nih.gov/pubmed/16513054

13. Neergaard J, Singh P, Job J, Montgomery S. Waterpipe smoking and nicotine exposure: a review of the current evidence. Nicotine Tob Res. 2007; 9(10):987-94. Available from: http://www.ncbi.nlm.nih.gov/pubmed/ 17943617\%0Ahttp://www.pubmedcentral.nih.gov/articlerender.fcgi?artid= PMC3276363

14. Combrink A, Irwin I, Laudin G, Naidoo K, Plagerson S, Mathee A. High prevalence of hookah smoking among secondary school students in a disadvantaged community in Johannesburg. S Afr Med J. 2010;100(5):297-9.

15. Van der Merwe N, Banoobhai T, Gqweta A, Gwala A, Masiea T, Misra M, et al. Hookah pipe smoking among health sciences students. S Afr Med J. 2013;103(11):847-9.

16. Christine A. Knowledge, attitude and practices of shisha smoking among youths in Kampala. In: Unpublished master thesis; Makarere university Uganda; 2015

17. Hakim F, Hellou E, Goldbart A, Katz R, Bentur Y, Bentur L. The acute effects of water-pipe smoking on the cardiorespiratory system. Chest. 2011;139(4): 775-81. Available from: http://www.ncbi.nlm.nih.gov/pubmed/21030492.

18. El Sherbiny NA, El Essawy A, Abdel Khalek EM. Knowledge and attitude towards smoking among Fayoum university students. Bulletin of High Institute of Public Health. 2010;40(3) Available from: http://www.fayoum.edu. eg/Medicine/ChestDiseases/pdf/DrAssem15.pdf (accessed 06 Apr 2018)

19. Martinasek MP, Haddad LG, Wheldon CW, Barnett TE. Beliefs and attitudes associated with hookah smoking among a United States college population. Respir Care. 2017;62(3):370-9. Available from: http://rc.rcjournal. com/content/62/3/370.

20. Chaaya M, El-Roueiheb Z, Chemaitelly H, Azar G, Nasr J, Al-Sahab B. Argileh smoking among university students: a new tobacco epidemic. Nicotine Tob Res. 2004;6(3):457-63. Available from: https://academic.oup.com/ntr/articleabstract/6/3/457/1131201?redirectedFrom=fulltext.

21. Bishop M. Shisha; the new craze in Kigali. In: The New Times | Rwanda; 2013. Available from: www.newtimes.co.rw/section/read/66116. Accessed 07 Aug 2016.

22. Manirakiza A. Shisha: smoking your way to death. In: The new times Rwanda; 2016

23. Republic of Rwanda Ministry of Health. Health Laws: Tobacco control law. 2013. Retrieved from: http://www.moh.gov.rw/fileadmin/templates/HLaws/ Tobacco_control_law.pdf (date accessed 7 Sept 2017).

24. Michielsen K, Beauclair R, Delva W, Roelens K, Van Rossem R, Temmerman $M$. Effectiveness of a peer-led HIV prevention intervention in secondary schools in Rwanda: results from a non-randomized controlled trial. BMC Public Health. 2012;12(1):729. Available from: http://bmcpublichealth. biomedcentral.com/articles/10.1186/1471-2458-12-729

25. Wosinski J. HIV risk among nursing students in Rwanda: self-efficacy, knowledge and attitudes. HIV Risk Among Nursing Students in Rwanda: Self-efficacy, Knowledge \& Attitudes. 2008. Available from: http://ezproxy. ithaca.edu:2048/login?qurl=http\%3A\%2F\%2Fsearch.ebscohost.com\%2Flogin. aspx\%3Fdirect\%3Dtrue\%26db\%3Dcin20\%26A N\%3D109850757\%26site\%3Dehost-live\%26scope\%3Dsite.

26. Van Decraen E, Michielsen K, Herbots S, Van Rossem R, Temmerman M. Sexual coercion among in-school adolescents in Rwanda: prevalence and correlates of victimization and normative acceptance. Afr J Reprod Health. 2012;16(3): 139-53. Available from: https:/tspace.library.utoronto.ca/bitstream/1807/ 61743/1/rh12051.pdf.

27. Republic of Rwanda Ministry of Education. National school health policy 2014 Retrieved from:https://hivhealthclearinghouse.unesco.org/sites/default/ files/resources/rwanda_school_health_policy.pdf. Accessed 10 June 2017.

28. Rwanda Ministry of Health Bans Shisha Smoking. The New Times | Rwanda. 2017. Retrieved from: www.newtimes.co.rw/section/read/225667. Accessed 12 Apr 2018.

29. WHO. Advisory note: Waterpipe Tobacco Smoking: health effects, research needs and recommended actions for regulators, WHO study Group on tobacco Product regulation (TobReg). 2nd ed; 2015. Retrieved from: http:// apps.who.int/iris/bitstream/handle/10665/161991/9789241508469_eng. pdf? sequenceAQ21=1.pdf. Accessed 20 Apr 2018.

30. World Bank. The World Bank DataBank. Data Bank 2016. Available from: http://databank.worldbank.org/data/reports.aspx?Code=NY.GNP.PCAP. CD\&id=1ff4a498\&report name=Popular-Indicators\&populartype= series\&ispopular=y. 
31. The Academic Registrar Office. Mount Kenya university. 2016.

32. Cochran WG. Sampling techniques. New York: John Wiley and Sons; 1977. p. 428

33. Parker M. Types of Sampling. Univ Texas Austin; 2013. p. 1-5. Available from: www.ma.utexas.edu/users/parker/sampling/srs.htm\#main.

34. Maziak W, Ward KD, Afifi RA, Eissenberg T. Standardizing questionnaire items for the assessment of waterpipe tobacco use in epidemiological studies. Public Health. 2005;119(5):400-4.

35. Norman G. Likert scales, levels of measurement and the "laws" of statistics. Adv Health Sci Educ: Theory Pract. 2010;15(5):625-32.

36. Viscusi WK. Age variations in risk perceptions and smoking decisions. Rev Econ Stat. 1991;73(4):577-88.

37. Bilodeau M, Brenner D. Theory of Multivariate Statistics. Springer. 1999;288. Available from: http://books.google.com/books?hl=en\&lr=\&id= 1 pa0VpPC8gsC\&oi=fnd\&pg=PP7\&dq=Theory+of+Multivariate +Statistics\&ots=2c5AHYjia1\&sig=GluX5kyJwKxlONsrnuz_BGUBhkE. Accessed 30 Nov 2017.

38. d'Amour MJ, Kwibuka E. Nationwide review of "Ubudehe" starts. In: The new times Rwanda; 2015

39. Jawad M, Lee JT, Millett C. Waterpipe tobacco smoking prevalence and correlates in 25 Eastern Mediterranean and Eastern European countries: cross-sectional analysis of the global youth tobacco survey. Nicotine Tob Res. 2016;18(4):395-402.

40. Zavery A, Qureshi F, Riaz A, Pervez F, labal N, Khan JA. Water pipe (shisha) use and legislation awareness against shisha smoking among medical students: a study from Karachi, Pakistan. J Community Health. 2017:42(3):461-5.

41. Jawad M, Nakkash RT, Mahfoud Z, Bteddini M, Haddad P, Afifi RA. Parenteral smoking and exposure to environmental tobacco smoke are associated with waterpipe smoking among youth: results from a national survey in Lebanon. Public Health. 2015;129(4):370-6. https://doi.org/10.1016/j.puhe. 2015.01.011

42. Gilreath TD, Leventhal A, Barrington-Trimis $J$, Unger JB, Cruz TB, Berhane $K_{\text {, }}$ et al. Patterns of alternative tobacco product use: emergence of hookah and E-cigarettes as preferred products amongst youth. J Adolesc Health 2016;58(2):181-5.

43. Mandil A, Hussein A, Omer H, Turki G, Gaber I. Characteristics and risk factors of tabacco consumption among University of Sharjah students, 2005. East Mediterr Heal J. 2007;13(6):1449-58.

44. Taha AZ, Sabra AA, Al-Mustafa ZZ, Al-Awami HR, Al-Khalaf MA, Al-Momen MM. Water pipe (shisha) smoking among male students of medical colleges in the eastern region of Saudi Arabia. Ann Saudi Med. 2010:30(3):222-6. https://doi.org/10.4103/0256-4947.62838

45. Ministry of Health Republic of Uganda. The tobacco control Act 2015. 2015. Retrieved from: http://health.go.ug/sites/default/files/Uganda_Tobacco_ Control_Act_0.pdf (accessed 10 Oct 2017).

46. Tanzania bans shisha smoking over health concerns. British Broadcasting Corporation (BBC) News. 2016. Retrieved from: www.bbc.com/news/worldafrica-36715088 (accessed 30 Sept 2017).

47. Mohammed H, Newman I, Tayeh R. Sheesha smoking among a sample of future teachers in Kuwait. Kuwait Med J. 2006:38(2):107-13.

48. Amin TT, Amr MAM, Zaza BO, Suleman W. Harm perception, attitudes and pradictors of waterpipe (shisha) smoking among secondary school adolescents in Al-Hassa, Saudi Arabia. Asian Pacific J Cancer Prev. 2010;11: 293-301. Available from: http://s3.amazonaws.com/academia.edu. documents/30693956/293_Tarewk_Amin.pdf?AWSAccessKeyld= AKIAJ56TOJRTWSMTNPEA\&Expires=1468914734\&Signature $=$ xZo1304bCGKkvbaspz6kWC4J2Yk\%3D\&response-content-disposition= inline\%3B filename\%3DHarm_perception_attitudes_and_pre

49. Sutfin EL, McCoy TP, Reboussin BA, Wagoner KG, Spangler J, Wolfson M. Prevalence and correlates of waterpipe tobacco smoking by college students in North Carolina. Drug Alcohol Depend. 2011;115(1-2):131-6.

50. Dugas E, Tremblay M, Low NCP, Cournoyer D, O'Loughlin J. Water-pipe smoking among North American youths. Pediatrics. 2010;125(6):1184-9. Available from: http://pediatrics.aappublications.org/content/125/6/1184.

51. Al MA. The prevalence of smoking among Karbala/lraq university students in Iraq in 2005. Tob use insights. 2014;7:9-14. Available from: http://www. pubmedcentral.nih.gov/articlerender.fcgi?artid=4335460\&tool= pmcentrez\&rendertype=abstract

52. Hussain HY, Abdul Satar BA. Prevalence and determinants of tobacco use among Iraqi adolescents: Iraq GYTS 2012. Tob Induc Dis. 2013;11(1):14. Available from: http://tobaccoinduceddiseases.biomedcentral.com/articles/ 10.1186/1617-9625-11-14
53. Nuzzo E, Shensa A, Kim KH, Fine MJ, Barnett TE, Cook R, et al. Associations between hookah tobacco smoking knowledge and hookah smoking behavior among US college students. Health Educ Res. 2013;28(1):92-100.

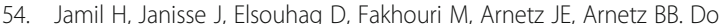
household smoking behaviors constitute a risk factor for hookah use? Nicotine Tob Res. 2011;13(5):384-8.

55. Eissenberg T, Ward KD, Smith-Simone S, Maziak W. Waterpipe tobacco smoking on a U.S. college campus: prevalence and correlates. J Adolesc Health. 2008:42(5):526-9.

56. Marcia JE. Development and validation of ego-identity status. J Pers Soc Psychol. 1966:3:551-8.

57. Jawaid A, Zafar AM, Rehman TU, Nazir MR, Ghafoor ZA, Afzal O, et al. Knowledge, attitudes and practice of university students regarding waterpipe smoking in Pakistan. Int J Tuberc Lung Dis. 2008;12(9):1077-84.

58. Al-Naggar Ra BY. Shisha smoking and associated factors among medical students in Malaysia. Asian Pac J Cancer Prev. 2012;13(11):5627-32.

\section{Ready to submit your research? Choose BMC and benefit from:}

- fast, convenient online submission

- thorough peer review by experienced researchers in your field

- rapid publication on acceptance

- support for research data, including large and complex data types

- gold Open Access which fosters wider collaboration and increased citations

- maximum visibility for your research: over $100 \mathrm{M}$ website views per year

At BMC, research is always in progress.

Learn more biomedcentral.com/submissions 